\title{
Prison Design and Carceral Space
}

Dominique Moran, Yvonne Jewkes and Jennifer Turner

\section{Abstract}

Prison design is crucial to the relationship between the 'carceral' and the state, in that it is the process which largely determines how the goals of a criminal justice system, and the wider society in which justice is enacted, are materially expressed. With this in mind, this chapter pursues the notion that the design of carceral space has a significant role to play in understanding the aims of a prison system and the experiences of living and working in prisons. After outlining the policy context for current UK prison building, the chapter describes the processes involved in the construction of new-build prisons and the imperatives (both overt and covert) which shape their design. It briefly draws out contrasts between the UK and penal regimes in other countries and suggests that both the intentions behind their design and the lived experience of the resulting prisons are worthy of further interrogation.

\section{Introduction}

Prison design is crucial to the relationship between the 'carceral' and the state, in that it is the process which determines, in large part, how the goals of a criminal justice system are materially expressed (Moran 2015). With this in mind, this chapter takes forward the notion of prison buildings as coded, scripted entities, exploring the design of prisons and the intentions behind their operation in terms of the imperatives of states and their criminal justice systems. It pursues the notion that the design of carceral space has a significant role to play in understanding the extent to which the aims of a carceral system are translated into experiences of imprisonment. 
Drawing on scholarship at the intersection between criminology and carceral geography (Moran 2015), the chapter begins by briefly tracing the history and significance of prison design, with a focus on the UK. It suggests that prison buildings can be read, and are experienced, as symbolic of the relationship between the 'carceral' and a punitive state - in terms of who prisoners 'are' and what they represent in the minds of those involved in producing the buildings in which to incarcerate them. Outlining the policy context for current UK prison building, the chapter then sketches out the processes involved in the construction of new-build prisons and the imperatives which shape their design; briefly draws out contrasts between the UK and other penal regimes; and suggests that both the intentions behind their design and the lived experience of the resulting prisons are worthy of further interrogation.

\section{Prison design}

[J]ails and prisons represent more than just warehouses of bed space for arrested or convicted men and women. They are more complicated environments than just good or bad, comfortable or not. The design of a jail or prison is critically related to the philosophy of the institution, or maybe even of the entire criminal justice system. It is the physical manifestation of a society's goals and approaches for dealing with arrested and/or convicted men and women, and it is a stage for acting out plans and programs for their addressing their future.

(Wener 2012: 7)

As this quote suggests, prison design is about more than accommodating and securing populations from whom society needs to be protected - although these two functions are themselves challenging and complex. The design of a prison reflects the penal 
philosophy of the prevailing social system; its ideas about what prison is 'for' and what it is considered to 'do'; and the messages about the purpose of imprisonment that it wants to communicate to prisoners, potential offenders and to society at large. As comparative criminology points out, offending behaviour is sanctioned in different ways in different places. Punishment and crime are argued to have very little to do with one another, with imprisonment rates 'to a great degree a function of criminal justice and social policies that either encourage or discourage the use of incarceration' (Aebi and Kuhn 2000: 66, cited in von Hofer 2003: 23; see also Tonry, 2004 and Sparks, this volume) rather than a function of the number of crimes that are committed. Imprisonment is not inevitable, therefore; rather it is a conscious choice about the appropriate response to offending behaviour, and the purpose of that response - in terms of the prevailing understanding of what it is that prison is intended to achieve both for society as a whole, and for offenders themselves (Moran 2015).

The following statement, made to The Guardian newspaper by Theresa May, the then UK Home Secretary, neatly sums up the intentions of imprisonment in the UK, as expressed by politicians to the electorate:

Prison works but it must be made to work better. The key for members of the public is that they want criminals to be punished. They want them to be taken off the streets. They also want criminals who come out of prison to go straight. What our system is failing to do at the moment is to deliver that for the public. And that's what we want to do.

(Guardian, 14 December 2010, see Travis 2010: no page) The notion that 'prison works' is of course highly contentious (see for example Burnett and Maruna 2004) but, in her statement, the Home Secretary communicated three 'aims' of imprisonment: to remove ('taking them off the streets'); to punish; and to 
rehabilitate ('going straight'). These aims characterise most prison systems, albeit the extent to which prison can achieve all, or indeed any, of these ends is highly debatable; and the balance between them - both as stated in public discourse, and as manifest and experienced in the criminal justice system itself - can vary widely. Just as prison design has yet to be foregrounded in academic literature, it also seems strangely largely disconnected from public discourses of imprisonment, despite being an integral part of prison commissioning and the expansion of the carceral estatei.

Whereas the United States and Western Europe are highly incarcerative (or perhaps hypercarcerative), other countries are by contrast decarcerative - actively deploying different techniques and sanctions to decrease their prison populations. This divergence reflects a different underlying principle of imprisonment. For example, a 'less eligibility' principle informs much prison policy in the US and Western Europe, based on an understanding that prisoners should 'suffer' in prison, not only through the loss of freedom but also by virtue of prison conditions, which should be of a worse standard than those available to the poorest free workers. In other contexts, such as in Finland, prison conditions are intended to correspond as closely as possible to general living conditions in society (Ministry of Justice of Finland, 1975). Penalties for offences are implemented in such a way that they do not unduly interfere with prisoners' participation in society, but as far as possible, promote it. The intention here is neither to oversimplify nor to romanticise the 'penal exceptionalism' of the Nordic countries (Pratt and Eriksson 2012, Ugelvik and Dullum 2012, Shammas 2014), but rather to point out that both the different philosophies of imprisonment and the different relative prison populations which these deliver, require and enable different intentions to be translated into the built form of prisons. 
With regard to Anglophone penal 'excess' rather than Nordic 'exceptionalism', as Theresa May's comments suggested, prisons must not only deliver a punished offender, but must do so in a way that satisfies the 'assumed punitiveness' of the public (Frost 2010, Garland 2001, Greer and Jewkes 2005, Hancock 2004, Young 2003); those whose apparent desire is for 'prisoners to be punished'. To these ends, prisons are subject to a new Government imposed 'public acceptability test' which, although devised to provide a check on educational and constructive activities that prisoners are permitted to undertake while serving their sentences (following negative media coverage of a comedy course at HMP Whitemoor), also impacts on ideas around what prisons should look like and feel like. UK prisons today must both punish and be seen to punish, as well as removing offenders from society in order to deliver some form of rehabilitation that reduces their future likelihood of reoffending. Although, as UK prison architecture has evolved, there has been no transparent, linear translation of 'punishment' into prison design, the interplay between philosophies of punishment and theories of prison design has resulted in preferred types of building thought capable of accomplishing the prevailing goals of imprisonment — which themselves have changed over time as penal philosophies have ebbed and flowed (Johnston 2000, Jewkes and Johnston 2007).

A comprehensive survey of the history of UK prison design and the interrelationships between the various influences that have affected it (considered in detail by Brodie et al 1999 and 2002, and Fairweather and McConville 2000), was discussed in depth by Jewkes and Johnston in the first edition of this Handbook (2007), and is beyond the scope of this chapter. However, considering prison buildings as scripted expressions of political-economic imperatives allows the aesthetics of prison buildings to be viewed as imbued with cultural symbolism (Moran and Jewkes forthcoming). Although, when focusing on the UK carceral estate there is no 'typical' 
prison, for the majority, exterior architectural features render them instantly recognisable, within that cultural context, as places of detention and punishment. Midnineteenth century prisons, for example, were built to resemble fortified castles (e.g. HMP Leeds, 1847), or gothic monasteries (e.g. Strangeways, 1868), and exterior facades communicated the perils of offending and the retributive power of the state. The twentieth century gradually saw a more utilitarian style reject the decorative aesthetic, communicating an ideal of modern, 'rational' justice and authority (Hancock and Jewkes 2011). In the 1960s and 1970s, new prisons such as Gartree and Long Lartin, whilst still communicating authority and efficiency, echoed the austere, functional styles of high, progressive modernism (ibid.). By the end of the twentieth century, UK prison architecture demanded higher walls, tighter perimeters and heightened surveillance in response to earlier escapes, riots and security breaches ${ }^{\mathrm{ii}}$, and in parallel with the rise of 'new punitiveness' in wider criminal justice policy. The evolution of prison architecture has at various points been intended to communicate a message about the nature of the imprisoning state and the legitimacy of its power to imprison, with the 'audience' for the various messages of this architecture being the inmate who receives the punishment handed down by the state, and society at large to whom imprisonment as punishment must be legitimated (Moran and Jewkes forthcoming).

\section{Research into Prison Design}

As early as the 1930s, architectural researchers pointed out the importance of prison design in shaping the experience of incarceration. In 1931, Robert Davison, former Director of Research for the Architectural Record, published a caustic article that castigated both US prison commissioners - for lack of knowledge about what they wanted new prisons to achieve — and penologists - for being 'surprisingly insensitive 
to the enormous importance of the building in the treatment of the prisoner' (1931: 39). Recognising that the design of prisons seemed to be a blind spot for the criminal justice system, he advocated that it was the job of the architect, even though they could 'scarcely be expected to be a penal expert', to indicate the 'necessity for a prolonged and careful study of this problem', and for a 'thorough research in [prison] building' (ibid.).

Despite the subsequent expansion of the penal estate and the immense investment in prison building in the UK and elsewhere, prison design has received remarkably little academic attention, and Davison's 'prolonged and careful study' is still to materialise. In the early 1960s, interest in new prison architecture and design reached its peak when a special issue of British Journal of Criminology was devoted to the topic. In subsequent decades, however, criminological interest in this subject seems to have waned; academic commentary on prison design has been sparse and its focus has been largely historical rather than contemporary, tracing the eighteenth- and nineteenth-century 'birth of the prison' (e.g. Johnston 2000). The dearth of scholarship on this topic is remarkable since the voices of prisoners, reflecting their experiences of incarceration in media such as autobiographies and poetry, speak vividly of prison design and its effects on the lived experience of incarceration (e.g. Boyle 1977, 1984, Hassine 2011, McWatters 2013). However, whilst criminological prison research has long been dominated by Sykes' (1958) notion of the 'pains of imprisonment', recent work has started to consider new and different ways of understanding the experience of incarceration, which lend themselves more readily to dialogue with the notions of carceral space and prison design. Encompassing discourses of legitimacy and nonlegitimacy (Sparks et al 1996); security (Drake 2012); therapy (Stevens 2012); compliance and neo-paternalism (Liebling with Arnold 2004, Crewe 2009); quality of life and healthy prisons (Liebling 2002, Liebling with Arnold, 2004); normalisation 
(Jewkes 2002); the depth, weight and tightness of imprisonment (Crewe 2009); the resurgence of the doctrine of less eligibility (White 2008); and public acceptability (Liebling with Arnold 2004), these studies hint at, if not fully articulating, a relationship between these notions and aspects of prison design.

The late 1980s saw a fleeting interest in prison design and prisoner wellbeing emerge within environmental psychology, with research identifying a link between physical environment and social climate (Houston et al 1988); and finding that prison architecture that creates overcrowded conditions causes significant stress to inmates (Schaeffer et al 1988). Although Canter (1987: 227) argued that a 'systematic, scientific evaluation of the successes and failures' of prison design was urgently required in order to explore this relationship further, no such evaluation has taken place. What is more, in the intervening period, research in environmental psychology has tended to focus its attention chiefly on negative prisoner behaviours and the risk factors that are perceived to contribute towards them; for example, focusing on 'hard' prevention techniques for prison suicide, such as developing cell designs with no ligature points from which prisoners can hang themselves. In other words, focus has shifted away from a concern for social climate, towards the designing-out of risk of physical harm from prisoners' destructive behaviour through environmental modification, and by maximising control on the part of the prison authorities (Tartaro 2003, Krames and Flett 2000). Recent attempts have been made to establish a broad-brush link between different architectural types and elements of prisoner behaviour: for example in the US between prison layouts (as determined by satellite imagery) and 'misconduct' on the part of inmates (Morris and Worrall 2010); and in the Netherlands between prison design and prisoner perceptions of interactions with prison staff (Beijersbergen et al 2014). These 
are tantalising studies, although their quantitative methodologies preclude further explication of the means by which any such linkages take form.

Despite, then, guarded transdisciplinary recognition that the design of carceral spaces has a direct effect on prisoner behaviour and control (Foucault 1979, Alford 2000), the lived environment of prisons, including its potential for positive experience, has been relatively overlooked. Moreover, the dominance of psychological methodologies in extant research on the prison environment has delivered rather a narrow range of largely quantitative studies, based on, for example: urine tests to determine stress responses (Schaeffer et al 1988); the deployment of suicide or misconduct statistics as a proxy for stress, towards which the physical environment might (or might not) be a contributory factor (Tartaro 2003, Morris and Worrall 2010); and true/false questionnaire responses as part of the Correctional Institution Environment Scale (CIES), which lacks an explicit environmental dimension; simply being used to measure 'wellbeing' in different institutions (Houston et al 1988). At the other end of the methodological spectrum, in his work with prisoner poetry, McWatters adds to understandings of how prison space is actually experienced by those for whom 'it is an ordinary space of daily life' (2013: 199), describing carceral space as 'more plastic, fluid and manifold than totalizing notions permit' (ibid.: 200), and arguing in support of efforts to expand the imaginary of lived spaces of incarceration.

Having recognised that the carceral environment 'matters' to prisoners' experiences, and having demonstrated it to some degree using a variety of methodologies, without exception, these studies call for a more nuanced investigation of the impact of design on those using and occupying prison spaces. 
Globally, the imprisonment of offenders takes place within a framework of primary international covenants and conventions, such as the Convention Against Torture and Other Cruel, Inhuman or Degrading Treatment or Punishment, which is intended to guarantee proper treatment for those in detention under all circumstances. These instruments do not set explicit standards for the treatment of prisoners, but they provide a means of monitoring basic standards of humane treatment. Driven by a concern for the treatment of those detained, these conventions do not extend to prescriptions about the exact nature of prison buildings, in terms either of their outward appearance and architectural style, or internal configuration.

Contemporary UK penal architecture reflects government reports commissioned within this policy context, which have transformed prison security and with it prisoners' quality of life (Liebling 2002, Liebling et al 2011, Drake 2012; see also Liebling this volume). A preoccupation with 'hardening' the prison environment to design-out risk through environmental modification coincided with the UK prison service becoming an executive agency in 1993, and with the early 1990s enabling of private contracts for the design, construction, management and finance of penal institutions. An approach to prison control based on a balance between situational and social control has arguably swung towards an understanding of the situational dependence of behaviour, 'creating safe situations rather than creating safe individuals' (Wortley 2002: 4).

In recent years, UK prison new-builds have been driven by logics of cost, efficiency and security. However, there is also a need to comply with HM Prison Service Orders about the specification of prison accommodation, which lay out 'measurable standards' that can be 'applied consistently across the estate' in order to enable the prison service to provide 'decent living conditions for all prisoners' (HMPS 2001: 1). In 
this context, prison exteriors have tended to adopt a bland, presumably cheap, unassuming and uniform style with vast expanses of brick, few, small windows and no unnecessary decoration (Jewkes 2013). Internally, the imperative in spending the Ministry of Justice’s approximate $£ 300$ million annual capital budget is to deploy indestructible materials to create custodial environments with no ligature points in which prisoners cannot physically harm themselves or others (RICS 2012). For example, one of the most recent UK prison new-builds, constructed as a part of the 'custodial architecture' portfolios of a specialist building contractor, was described as 'very operationally efficient' with 'a modern custodial aesthetic'iii. Advertising their 'Custodial and Emergency Services' project capabilities, the contractor, whilst conceding the need for a prison building to 'have a positive impact' and to be 'safe, nonthreatening, secure and aesthetically pleasing', highlighted the imperative for 'value for money [to] be carefully balanced against the need for robustness and security'. Their experience and expertise in this area was described as bringing 'efficiencies at the design stage' including the kind of modified environments that create safe situations (Wortley 2002), such as 'designing ligature free environments by incorporating junctions and fixing details within structural walls and floors' (Pick Everard no date: no page).

Nineteenth-century prison buildings still in service are usually considered the least desirable environments within the UK penal estate. But while these Victorian 'houses of correction' ensured inmates' restricted economy of space, light and colour, imprisoning psychologically as well as physically, it has yet to be established empirically whether 'old' always means 'bad' or whether the kind of 'contemporary' prison described above necessarily equates to 'progressive' or 'humanitarian' (Hancock and Jewkes, 2010; Moran and Jewkes, forthcoming). For example, within a year of re- 
opening in 1983, the 'new' Holloway Prison was criticised by the UK Prisons Inspectorate as engendering a form of torture that could result in acute mental illness. Levels of self-harm, suicide and distress were high and vandalism, barricading of cells, floodings, arson and violence against other prisoners and staff were common (Medlicott 2008). Among interior layouts recently advocated to manage problems like these is the 'new generation' campus-style arrangement of discrete housing units connected by outdoor space and flexible planning and design. Such prisons have experienced different levels of success. Although prison architecture may reflect underlying penal philosophies, the ways in which it is experienced depend heavily on local contingencies and on the human subjectivity of the habitation of buildings. For example, Feltham and Lancaster Farms Young Offenders Institutions have been perceived differently on issues such as bullying, self-harm and suicide. Lancaster Farms has been held up as a shining example of commitment and care, whilst Feltham's reputation is coloured by years of damning reports and a high-profile murder (Jewkes and Johnston 2007).

The 'new punitiveness', discussed earlier with regard to the relationship between the carceral and the state, comes clearly into view when considering the prison estate. Latterly, it has expanded to accommodate those imprisoned under circumstances of increasing (and, increasingly, indeterminate) prison sentences, more punitive prison sanctions, and more austere and spartan prison conditions, operating to a greater or lesser extent in various contexts (Pratt et al 2013, Hallsworth and Lea 2011, Lynch 2011, Snacken 2010). This hardening of penal sensibilities is coupled in the UK and elsewhere with more severe sentencing policies (Criminal Justice Act 2003); the fetishising of risk and security within and outside the penal estate; and a rising prison population (which, in England and Wales, grew by 30 per cent since 2001 and stood at 85,414 in June 2014). All of this makes questions of prison design and the lived 
experience of carceral space particularly pertinent. Although chronic overcrowding, high rates of drug use, mental illness, self-harm and suicide, recidivism and its associated financial and social costs, mar the UK system, abscondments from closed prisons have fallen dramatically, due in part to prison design: prison walls are higher, prison space is sequestered through zoning, and CCTV cameras and other technologies proliferate.

In the United States, perceived public endorsement for rigorous and unpleasant conditions have also resulted in new prisons being built with 'a level of security above "high security"' and internal routines not seen for 150 years (Johnston, 2000: 4). Morin (2013: 381) has argued that the 'latest punitive phase' in the US neither simply eliminates, as in the premodern spectacle, nor creates the docile, rehabilitated bodies of the modern Panopticon. Rather, she argued that the late-modern prison 'produces only fear, terror, violence, and death'. In support of this view, Victor Hassine, a 'lifer' who committed suicide after serving 28 years in various correctional facilities in the States, comments on the 'fear-suffused environments' he endured, and writes:

To fully understand the prison experience requires a personal awareness of how bricks, mortar, steel, and the endless enforcement of rules and regulations animate a prison into a living, breathing entity designed to manipulate its inhabitants...Prison designers and managers have developed a precise and universal alphabet of fear that is carefully assembled and arranged - bricks, steel, uniforms, colors, odors, shapes, and management style - to effectively control the conduct of whole prison populations (2011: 7). 
Recent work within carceral geography has addressed the significance of carceral space (Moran et al 2013, Moran 2015), recognising space as more than the surface where social practices take place (Gregory and Urry 1985, Lefebvre 1991, Massey 1994). Although geographers understand that space can affect the ways people act within it and are increasingly applying this perspective to carceral spaces, Siserman (2012) points out that studies of prisons as buildings and environments where the behaviour of inmates can be dramatically changed, and which investigate how this might happen, remain scarce. Commentaries within architectural geographies and cultural geographies have argued for the importance of considering buildings in a number of connected ways (e.g. Kraftl 2010, Jacobs and Merriman 2011, Rose et al. 2010, Jacobs 2006, Kraftl and Adey 2008): as everyday spaces in which people spend a significant proportion of their lives; as expressions of political-economic imperatives that code them with 'signs, symbols and referents for dominant socio-cultural discourses or moralities' (Kraftl 2010, 402); and in terms of perspectives that emphasise materiality and affect.

A representationalist focus on prison buildings as sites of meaning, symbolic of intentions and imperatives is itself arguably underdeveloped in prison scholarship. However, there is the potential to go beyond the symbolic meaning of prison buildings to consider the 'inhabitation' (Jacobs and Merriman 2011: 213) in terms of the dynamic encounters between these buildings and their constituent elements and spaces, design, planners, inhabitants, workers, visitors, and so on. Like any other buildings, prisons are sites in which a myriad of users and things come into contact with one another in numerous complex, planned, spontaneous and unexpected ways; and where the encounters are both embodied and multi-sensory, and resonant of the power structures that exist both within and beyond the prison building, and which shape its inhabitation. 
Recent developments in both prison architecture and design (albeit outwith the context of the 'new punitiveness') and criminological research into prison aesthetics and 'anaesthetics' (Jewkes 2013) echo Kraftl and Adey's suggestion that one function of buildings can be an attempt to stabilise affect, 'to generate the possibility of precircumscribed situations, and to engender certain forms of practice, through the design and planning of buildings, including aspects such as form and atmosphere' (2008: 228). In their work, they found that certain generic expressions of affect evoked certain kinds of inhabitation, materialised via buildings in their 'potential capacities to affect their inhabitants in certain ways' (ibid.). In other parts of the world - in which the 'new punitiveness' of the US, UK and elsewhere has not taken hold - prison designers have focused on the rehabilitative function of imprisonment, and have experimented with progressive and highly stylised forms of penal architecture. There, internal prison spaces exhibit soft furnishings, colour zoning, maximum exploitation of natural light, displays of art and sculpture, and views of nature through vista windows without bars.

For example, in designing a planned women's prison in Iceland, the project team from 00IIO Architecture intended:

to design a prison that doesn't look like a prison, forgetting about dark spaces, small cells, and ugly grey concrete walls ... we based the building design on natural light, open spaces, and natural green materials like peat, grass and flowers.

(OOIIO Architecture 2012: no page) Instead of designing one large building (like a 'typical repressive old prison'), they decided to break it into several 'human-scale, connected' pavilions, which must be efficient and functional to enable the spatial separation of prisoners, but must also have 
'natural light and exterior views, to increase the feeling of freedom'. The architects also had an eye to the speed and ease of construction, and to the eco standards of the building, planning to draw upon Icelandic vernacular architecture to insulate the building. With a facade constructed from peat-filled cages planted with local flowers and grasses, they intended to deliver a building 'that changes with the seasons', making prison life 'less monotonous and more human and natural related' (ibid.).

This kind of design of new prisons in Norway, Iceland and Denmark, arguably plays up and enhances certain generic expressions of affect connected to openness, flexibility and 'humane' treatment. It evokes certain kinds of inhabitation that encourage personal and intellectual creativity, and even a lightness and vividness of experience (Hancock and Jewkes 2011). Away from this Nordic context, however, what drives the building of new prisons in the UK, and how much do we know about it?

\section{Building new prisons in the UK}

Kraftl and Adey (2008: 228) called for further research into the ways in which architectural forms try to manipulate and create possibilities, and into how those affects are experienced and negotiated in practice, via the notion of inhabitation. Attending to the processes of architectural design and construction reveals the multiple political, affective and material ways in which prison buildings are designed and constituted. These in in turn play a part in constructing the affectual potentialities of prison buildings that are negotiated in and through practices of inhabitation.

The design process, is, as Wener noted, 'the wedge that forces the system to think through its approach and review, restate, or redevelop its philosophy of criminal justice' (2012: 7). Embedded within this process is the conscious and intentional design of carceral spaces, in response to contingent policy imperatives and in the context of 
local budgetary constraints. In the UK, the contemporary process of designing and building new prisons now rests upon a complex and varied framework with an intricate network of individuals, companies and capital, and is driven primarily by concerns for security, cost and efficiency; concerns which materially shape the buildings themselves. Since the recommendation of the 1987 Select Committee on Home Affairs report that the Home Office should enable private companies to tender for the management of prisons, the landscape of UK prison construction had shifted considerably. The 1990 Criminal Justice Bill provided enabling legislation for prison privatisation, and Section 84 of the Criminal Justice Act 1991 allowed for the private running of new prisons. These 'Manage \& Maintain' (M\&M) contracts involved the then Ministry of Prisons leasing prisons to private operators contracted to run them, and maintain their buildings and infrastructure, for 15 years. The Conservative government's introduction in 1992 of the Private Finance Initiative (PFI) enabled 'Public-Private Partnerships' (PPPs) to fund public infrastructure projects with private capital, and the 1994 Criminal Justice and Public Order Act allowed for the private provision as well as the operation and maintenance of prisons. Following a tendering process in which the public sector was barred from participating, Group 4 (now G4S) was awarded a contract to manage HMP Wolds, a newly built remand prison that opened in April 1992. What started as an 'experiment', however, soon became routine policy (Panchamia, 2012) and, in 1997, the incoming New Labour government adopted PFI. HMP Altcourse in Liverspool, and HMP Parc, at Bridgend in Wales, became the first PFI builds under Labour in England and Wales respectively.

Now known as Design, Construct, Manage and Finance (DCMF) contracts, PFI builds involve private sector finance for the construction of new prisons, as well as to provide their custodial services. A consortium of financers, constructors, and a facilities 
operator form a special purpose- or operating vehicle known as an 'SPV' or 'SOV', which, in a PFI, carries the profit or loss from the venture. The Secretary of State contracts with the SPV which, in turn, subcontracts the immediate construction to a Design and Build Contractor (D\&B), and the long-term operation of the prison to a Buildings and Facilities Management company (BFM), typically for 25 years. In some cases in the UK, prisons are still built and run using public funds; whereas others may be publicly financed, but operated by private companies under 'Manage and Maintain' (M\&M) contracts. Recent examples of these generic types of construction in the UK include HMP Oakwood (opened 2012 - M\&M) in Staffordshire, HMP Thameside (2012 - DCMF) in London, and HMP Grampian (2014 - public funds and publicly run) in northern Scotland.

In terms of the build process itself, contractors who have had previous success delivering prisons on time and within budget tend to be commissioned for subsequent projects. At HMP Thameside, for example:

Skanska brought together its in-house expertise in construction, piling, structural and civil design, and the installation of mechanical and electrical services to deliver the project. It also built on its experience from similar projects, such as the HMP Dovegate project in Staffordshire.

(Skanska 2012: 1)

Experience is important, therefore, but so is cost; in the case of the planned prison HMP North Wales, four main contractors were in competition: Carillion, Interserve, Lend Lease and Kier. Lend Lease's award of the contract in May 2014 perhaps rewarded a projected build cost of $£ 212$ million, 15 per cent below the government's original planned budget of $£ 250$ million, as well as a commitment to spend $£ 50$ million with 
small and medium enterprises, and $£ 30$ million with local businesses. For a government eager to stimulate local economic activity and development, Lend Lease's plan to recruit 50 per cent of the site workforce from the local area, including around 100 apprenticeships (Morby, 2014) may also have increased the attractiveness of their bid. The cost of operation is also critical; HMP Oakwood, for example, accommodates up to 2,000 prisoners relatively cheaply (at $£ 13,200$ per inmate per year compared to the England and Wales average of $£ 21,600$ per year for Category $C$ prisoners and $£ 31,300$ for all prisoners). The G4S-run facility has been lauded as a 'model' prison by the Secretary of State for Justice.

In terms of the built form of new prisons, cost concerns, in relation to both building materials and build duration, heavily influence the fabric of the resulting facility. In order to reduce both the build time and the on-site workforce, off-site prefabrication is preferred. HMP Oakwood, for example, consists of 12 precast buildings, including four four-storey house blocks, and entry and facilities buildings. These buildings were quickly assembled on site from precast concrete panels with window grilles, sanitary provisions and drainage pre-installed. At HMP Thameside, Skanska coordinated a similar process of the delivery of off-site precast concrete components, the use of which facilitated swift construction on the small and confined site, allowing some buildings to be handed over 14 weeks early (Skanska 2012: 1). In prison building, time is money. Whilst HMP Grampian was under construction, prisoners from closed prisons at Aberdeen and Peterhead had to be held elsewhere (Premier Construction 2014). Finishing on time and on budget meant that they could be rehoused quickly, with minimal additional cost, security worries or disruption to their sentence planning.

The pre-eminence of financial considerations shapes a government procurement process that is arguably engineered towards the most cost-effective solution. In a 
prevailing climate of cuts to justice spending, contractors who have delivered previous projects on time and on budget are well placed to win subsequent tenders. This has two implications. First, breaking into the marketplace as a new SPV/D\&B company is difficult, as newcomers face considerable disadvantages. Second, and connectedly, alternative or experimental prison designs which deviate from a 'tried and tested' template amenable to precast construction and on-site assembly may simply be priced out of the market. This often, and perhaps understandably, results in contractors sticking to designs whose construction costs and build times they can confidently predict, in order to bid competitively for new contracts. What this effectively means is that new prisons tend to be virtually identical to other recently built prisons (Jewkes and Moran 2014), with architectural aesthetics taking a backseat, and innovation limited to efficiency of build, rather than creativity of design.

\section{Discussion}

In addition to the conscious and intentional meanings attached to carceral spaces (relating to cost, reliability, security, and so on) that are embedded in the procurement and contracting processes outlined above, research on emotional geographies of prisons (Crewe et al 2013) highlights the more subtle ways in which architecture and design communicate the aims and techniques of penal authority. We have argued elsewhere that the large, bland prison warehouses that are now built in the contemporary UK may communicate a particular message about society's attitudes to prisoners (Jewkes and Moran 2014). The nondescript external appearance of new-build prisons could be regarded as a visual metaphor for the loss of public empathy for the excluded offender, where 'municipal' architecture enables us to turn a blind eye to the plight of the confined. Although such a benign façade might suggest a benevolent regime, it has 
recently been argued that concerns for security within many countries' penal systems have risen to such a level of prominence that they eclipse almost every other consideration, including what it means to be human (Drake 2012). In this context, the benign exterior can mask a sterile, 'mean-spirited', assembly line quality (Hassine 2011: 125).

The penal philosophies and imperatives underpinning the design of newlycommissioned and newly-built facilities thus shape the relationship between space, meaning and power, and have an undeniable impact on the experience of imprisonment and on the behaviour of those who occupy and move through carceral spaces. The 'dynamic encounters' (Jacobs and Merriman 2011: 213) that occur between the inhabitants of prison buildings, the technologies operational within them, and the buildings themselves, are critical to understanding their inhabitation. Criminologists recognise that prisoners constantly 'manage' issues of self and identity and adapt socially under intense and inescapable duress; and the kinds of encounters between prisoners and prison staff that are encouraged by, or which are even possible within, differently designed prison buildings are worthy of investigation. 'Dynamic security', in which prison staff are encouraged to develop good relationships with prisoners through direct contact and conversation, is no longer possible in many new build prisons where staff are physically separated from prisoners.

Where surveillance technologies enhance the observation of carceral space, some prisoners may value CCTV as a means of protecting their personal safety and for its capacity to provide evidence of bullying and assaults. However, these technologies also reinforce the absence of privacy and create additional stresses for both prisoners and staff (Liebling et al, 2011). The utilisation of surveillance and monitoring technologies in prisons as workplaces have inevitably brought prison employees under 
closer scrutiny from their managers (Townsend and Bennett 2003, Ball 2010), and it is argued that the notion of trust, once regarded as essential to prison management-staff relationships, has been undermined by surveillance systems that ensure that 'correct' organisational procedures are followed. Increasingly, prisons routinely monitor everyone passing through them via an interface of technology and corporeality, encouraging flexibility of movement while retaining high levels of security. For example, cameras wirelessly transmit digital images, which are then screened for unusual objects and atypical movements; biometric and electronic monitoring of prisoners and visitors allow the tracking of bodies within in the prison; listening devices monitor the spectral content of sound to spot illicit use of mobile phones or early signs of aggressive behaviour; and prison officers' Blackberry-style devices enable immediate reports to be relayed to Security (OIS 2008; cited in Hancock and Jewkes 2011).

Whereas Morin's (2013) work suggested that like the UK, the US is experiencing a trend towards increasingly severe and restrictive prison designs, elsewhere, prison buildings are being designed with different intentions in terms of the manipulation and creation of possibilities. In northwest Europe, decarcerative policies deliver smaller numbers of prisoners, and for these smaller prison populations the use of surveillance technologies facilitate 'humane', open-plan, 'progressive' prisons with a greater degree of movement among and between inmates and staff, and a wider range of possible encounters. Here, new build prisons are not only the result of experimentation with progressive and highly-stylised forms of penal architecture, but they also have internal prison spaces that explore more open, flexible and normalised spatial planning than is the norm in the UK. Among the design features to be found in these new prisons are: soft furnishings replacing hard fixtures and fittings; zoning different parts of the prison through colour coding and use of psychologically effective colour schemes; attention to 
the maximum exploitation of natural light and/or artificial light that mimics daylight; greater access to outdoor spaces with trees, planting and water features; the incorporation of differing levels, horizons and building materials to ward off boredom and monotony; and displays of art and sculpture (Hancock and Jewkes, 2011, Moran and Jewkes forthcoming). This kind of strategic application of architectural and aesthetic principles to the design of new prisons in, for example, Norway, Iceland and Denmark, has been found to encourage personal and intellectual creativity, and even a lightness and vividness of experience (Hancock and Jewkes 2011), in contrast to the depth, weight and tightness commonly associated with imprisonment (Crewe, 2011) and its material darkness, even hellishness (Wacquant, 2002, Jewkes, 2014, Jewkes forthcoming). Even in the Nordic countries, however, prison design may not be straightforwardly humane and positive - or may at least have perverse consequences. For example, although the appearance of these prison buildings - in terms of their natural materials, large windows and natural light - conveys a sense of ease and relaxation, it arguably replicates and perhaps enhances some of the issues of privacy, identity management and presentation of self-identity in more-obviously 'restrictive' settings. Meanwhile, Shammas (2014: 104) has called for attention to be paid to the 'pains of freedom' inherent in Norway's more 'humane' prisons. There is some evidence that technology-assisted, decentralised, podular designs approximate 'normality' by providing safer and more comfortable living environments, and removing security gates, bars and grilles, enabling prison officers to be more than 'turn-keys' (Spens 1994). But as Hancock and Jewkes (2011) have argued, there has been scant official or scholarly discussion of other potential uses of technology, such as the identification of abuse or aggressive behaviour by prison officers (either to prisoners or their colleagues), the surveillance of staff smuggling contraband into the prison, or behaving 
in ways disapproved of by prison authorities. Similarly, there is little debate about the moral and ethical implications of near-constant surveillance of prisoners and officers, or the difficulties in establishing trust when basic standards of privacy are compromised. The use of technologies could exacerbate complex horizontal and vertical relationships between prison inmates, officers, managers and ministers. Everyone who moves within and through these 'hyper-organizational spaces' (Zhang et al 2008) is not only enmeshed in a surveillance assemblage that forces them to manage their own presentation of self within the regulative framework of the institution, but is further encouraged to watch while knowingly being watched. Although lack of privacy has long been recognised as a 'pain of imprisonment' for inmates, for prison staff the new Panopticism is a novel form of control (Hancock and Jewkes 2011).

\section{Conclusion}

With Wener's (2012: 7) proposition that 'the design of a jail or prison is critically related to the philosophy of the institution, or maybe even of the entire criminal justice system', a better understanding of prison design could in turn enable a better understanding of the lived experience of carceral spaces - a central theme of recent research in carceral geography. Geographers have made valuable contributions to understandings of how, even within the most restrictive conditions of confinement, prisoners employ effective spatial tactics within surveilled space; create individual and collective means of resistance to carceral regimes; and succeed in appropriating and personalising carceral spaces (Moran and Jewkes forthcoming). Yet, the majority of research to date has tended to focus on inmate responses to, and adaptations of, the physical spaces of incarceration, rather than drawing attention to the processes that led those spaces to be as they are, and what this means for the ends prison buildings serve 
for the state that creates them. Missing from this work is a consideration of the ways in which punitive philosophies are manifest in prison commissioning and construction, and subsequently in prison buildings themselves.

The challenge, therefore, is to start to address why those spaces are as they are, and to interrogate the intentions behind their design. Returning to Davison's (1931) condemnation of US prison design, research needs to further illuminate the commissioning process, to uncover what it is that architects are asked to draw, contractors to build and facilities managers to maintain, and how those demands are articulated and addressed. Davison argued that prison authorities would 'never get the most out of their architects until specifications are presented not in terms of definite plans and materials, but in terms of performance' (1931: 33). He called for commissioners not to request cell blocks, but sleeping places; not to demand mechanical ventilation, but instead to require good air for every prisoner. Then, he concluded, 'let the solution be worked out. In many instances the result will be astonishing. It will not resemble the present jail at all' (ibid.: 34). Designing a prison based on the requirements of the building, rather than simply accepting and replicating what has been built before, was for him, the key to delivering 'better' prisons.

Pursuing these questions could enable us to not only better understand the experience of incarceration, but also to open the design process itself to scrutiny and reflection (Moran and Jewkes forthcoming, Jewkes and Moran 2014)iv. Wener (2012: 7) argued that prison environments represent both an 'overt' agenda that provides measurable quantities of space for accommodation, training, therapy, education and so on, but also a 'covert' agenda that reflects what or who inmates 'are' in the minds of planners, designers, and those who commission them to design and build prisons. 
Opening a space for the articulation of this 'covert' agenda could contribute positively to the on-going debate over the expansion of the penal estate.

\section{Further reading}

One of the many informative large-format books on prison architecture and design is the collection edited by Fairweather and McConville (2000) Prison Architecture: Policy, Design and Experience, Oxford: Architectural Press, which contains contributions from some of the leading experts in prison design from the worlds of architecture, the Prison Service and Inspectorate, and academia. Also impressive is Spens, I. (ed) (1994) Architecture of Incarceration, London: Academy Editions. The emerging field of carceral geography has produced several works referenced in this chapter, including: Moran, D. (2015) Carceral Geography: Spaces and Practices of Incarceration, Farnham: Ashgate; and Moran, D., Gill, N. and Conlon, D. (eds) (2013) Carceral Spaces: Mobility and Agency in Imprisonment and Migrant Detention, Farnham: Ashgate, in which all the authors of this chapter have contributions. Finally, Yvonne Jewkes has written on the hellish environments in which extreme punishments are carried out, comparing the modern prison to the Inferno described in Medieval times by Dante; see her chapter in K. Reiter and A. Koenig (eds.) Extraordinary Punishment: An Empirical Look at Administrative Black Holes in the United States, the United Kingdom, and Canada, London: Palgrave.

\section{References}

Adey, P. (2008) 'Airports, mobility and the affective architecture of affective control', Geoforum, 39: 438-51. 
Aebi, M.F. and Kuhn, A. (2000) 'Influences on the prisoner rate: number of entries into prison, length of sentences and crime rate', European Journal on Criminal Policy and Research 8(1): 65-75.

Alford, C.F. (2000) 'What would it matter if everything Foucault said about prison were wrong? Discipline and Punish after twenty years', Theory and Society, 29(1): 125-46.

Allen, J. (2006) ‘Ambient power: Berlin's Potsdamer Platz and the seductive logic of public spaces', Urban Studies, 43: 441-55.

Ball, K.S. (2010) 'Workplace surveillance: an overview', Labor History, 51(1): 87-106.

Beijersbergen, K.A., Dirkzwager, A.J.E., van der Laan, P.H. and Nieuwbeeerta, P. (2014) ‘A Social Building? Prison Architecture and Staff-Prisoner Relationships' Crime \& Delinquency, DOI: 10.1177/0011128714530657.

Boyle, J. (1977) A Sense of Freedom, London: Pan.

- - (1984) The Pain of Confinement, Edinburgh: Canongate.

Brodie, A., Croom, J. and Davies, J.O. (1999) Behind Bars: The Hidden Architecture of England's Prisons, London: English Heritage.

—— (2002) English Prisons: An Architectural History, London: English Heritage.

Burnett, R. and Maruna, S. (2004) 'So 'prison works', does it? The criminal careers of 130 men released from prison under Home Secretary, Michael Howard', The Howard Journal of Criminal Justice, 43(4), 390-404.

Canter, D. (1987) 'Implications for "new generation" prisons of existing psychological research into prison design and use', in Bottoms A.E. and Light, R. (eds) Problems of Long-term Imprisonment, Gower: Aldershot.

Crewe, B. (2009) The Prisoner Society: Power, Adaption, and Social Life in an English Prison, Oxford: Oxford University Press. 
Crewe, B., Warr, J., Bennett, P., and Smith, A. (2013) 'The emotional geography of prison life', Theoretical Criminology, DOI: 1362480613497778.

Great Britain (1991) Criminal Justice Act 1991, London: The Stationery Office. Online. Available HTTP: http://www.legislation.gov.uk/ukpga/1991/53/contents (accessed 4 July 2014).

- - (1994) Criminal Justice and Public Order Act 1994, London: The Stationery Office. Online. Available HTTP:

http://www.legislation.gov.uk/ukpga/1994/33/contents (accessed 4 July 2014).

_- (2003) Criminal Justice Act 2003, London: The Stationery Office. Online. Available HTTP: http://www.legislation.gov.uk/ukpga/2003/44/contents (accessed 4 July 2014). Davison, R.L. (1931) 'Prison architecture', Annals of the American Academy of Political and Social Science, 157: 33-39.

Drake, D. (2012) Prisons, Punishment and the Pursuit of Security, London: Palgrave Macmillan.

Fairweather, L. and McConville, S. (eds) (2000) Prison Architecture: Policy, Design, and Experience, Oxford: Elsevier.

Foucault, M. (1979) Discipline and Punish: The Birth of the Prison, New York: Vintage.

Frost, N.A. (2010) 'Beyond public opinion polls: punitive public sentiment and criminal justice policy', Sociology Compass, 4(3): 156-68.

Garland, D. (2001) The Culture of Control, Oxford: Oxford University Press.

Greer, C. and Jewkes, Y. (2005) 'Extremes of otherness: media images of social exclusion', Social Justice, 32(1): 20-31.

Gregory D. and Urry, J. (eds) (1985) Social Relations and Spatial Structures, London: Macmillan. 
Hallsworth, S. and Lea, J. (2011) 'Reconstructing Leviathan: emerging contours of the security state', Theoretical Criminology, 15(2): 141-57.

Hancock, L. (2004) 'Criminal justice, public opinion, fear and popular politics', in Muncie, J. and Wilson, D. (eds) The Cavendish Student Handbook of Criminal Justice and Criminology, London: Cavendish.

Hancock, P. and Jewkes, Y. (2011) 'Architectures of incarceration: the spatial pains of imprisonment', Punishment and Society, 13(5): 611-29.

Hassine, V. (2010) Life Without Parole: Living and Dying in Prison Today, New York: Oxford University Press.

Her Majesty's Prison Service [HMPS] (2001) Prison Service Order 1900: Certified Prisoner Accommodation, London: HMPS.

Houston, J.G., Gibbons, D.C. and Jones, J.F. (1988) 'Physical environment and jail social climate', Crime \& Delinquency, 34(4):449-66.

Hurd, D. (2000) Memoirs, London: Little Brown.

Jacobs, J.M. (2006) 'A geography of big things', Cultural geographies, 13(1): 1-27.

Jacobs, J.M. and Merriman, P. (2011) 'Practising architectures', Social \& Cultural Geography, 12(3): 211-22.

Jewkes, Y. (2002) Captive Audience: Media, Masculinity and Power in Prisons, London: Routledge.

- - (2013) 'On carceral space and agency', in Moran, D., Gill, N. and Conlon, D. (eds) Carceral Spaces: Mobility and Agency in Imprisonment and Migrant Detention, Farnham: Ashgate.

- - (forthcoming) 'Fear-suffused hell-holes: the architecture of extreme punishment', in Reiter, K. and Koenig, A. (eds) Extraordinary Punishment: An Empirical Look at Administrative Black Holes in the United States, the United Kingdom, and Canada, London: Palgrave. 
Jewkes, Y. and Johnston, H. (2007) 'The evolution of prison architecture', in Jewkes, Y. (ed.) Handbook on Prisons, London: Routledge.

Jewkes, Y. and Moran, D. (2014) 'Should prison architecture be brutal, bland or beautiful?', Scottish Justice Matters, 2(1): 8-11.

Johnston, N. (2000) Forms of Constraint: A History of Prison Architecture, Urbana, IL: University of Illinois Press.

Kraftl, P. (2010) 'Geographies of architecture: the multiple lives of buildings', Geography Compass, 4(5): 402-415.

Kraftl, P. and Adey, P. (2008) 'Architecture/affect/inhabitation: geographies of being-in buildings', Annals of the Association of American Geographers, 98(1): 213-31.

Krames, L., and Flett, G.L. (2002) The Perceived Characteristics of Holding Cell Environments: Report of a Pilot Study, Canadian Police Research Centre.

Leech, M. (2005) The Prisons Handbook, Manchester: MLA Press.

Lefèbvre, H. (1991) The Production of Space, Oxford: Blackwell.

Liebling, A. (2002) Suicides in Prison, London: Routledge.

Liebling, A. with Arnold, H. (2004) Prisons and their Moral Performance: A Study of Values, Quality, and Prison Life, Oxford: Oxford University Press.

Liebling, A., Arnold, H. and Straub, C. (2011) An Exploration of Staff-Prisoner Relationships at HMP Whitemoor: Twelve Years On, London: MOJ.

Lynch, M. (2011) 'Mass incarceration, legal change, and locale', Criminology \& Public Policy, 10(3): 673-98.

Massey, D. (1994) Space, Place and Gender, Cambridge: Polity Press.

McWatters, M. (2013) 'Poetic testimonies of incarceration: towards a vision of prison as manifold space', in Moran, D., Gill, N. and Conlon, D. (eds) Carceral Spaces: Mobility and Agency in Imprisonment and Migrant Detention, Farnham: Ashgate. 
Medlicott, D. (2008) 'Women in prison' in Jewkes, Y. and Bennett, J. (eds) Dictionary of Prisons and Punishment, London: Routledge.

Ministry of Justice of Finland (1975) Statute on Prison Administration, Helsinki: Ministry of Justice.

Moran, D. (2015) Carceral Geography: Spaces and Practices of Incarceration, Farnham: Ashgate.

Moran, D., Gill, N. and Conlon, D. (eds) (2013) Carceral Spaces: Mobility and Agency in Imprisonment and Migrant Detention, Farnham: Ashgate.

Moran, D. and Jewkes, Y. (forthcoming) 'Linking the carceral and the punitive state: researching prison architecture, design, technology and the lived experience of carceral space', Annales de la Geographie.

Morby, A. (2014) 'Lend Lease wins £212m Wrexham super prison', Construction Enquirer. Online. Available HTTP:

http://www.constructionenquirer.com/2014/05/30/lend-lease-wins-212m-wrexhamsuper-prison/ (accessed 19 June 2014).

Morin, K.M. (2013) “Security Here is Not Safe': Violence, Punishment, and Space in the Contemporary US Penitentiary', Environment and Planning D: Society and Space, 31(3): 381-99.

Morris, R.G., and Worrall, J.L. (2010) 'Prison architecture and inmate misconduct: a multilevel assessment', Crime \& Delinquency, DOI: 10.1177/0011128710386204. Offender Information Services (OIS) (2008) Prison Technology Strategy. Version 0.8, London: NOMS.

OOIIO Architecture (2012) Female prison in Iceland, OOIIO Architecture website. Online. Available HTTP: http://plusmood.com/2012/06/female-prison-in-iceland-ooiioarchitecture/ (accessed 2 February 2014). 
Panchamia, N. (2012) 'Competition in prisons', London: Institute for Government. Available HTTP:

http://www.instituteforgovernment.org.uk/sites/default/files/publications/Prisons\% 20briefing\%20final.pdf (accessed 22 July 2014).

Pick Everard (2012) 'Pick Everard completes UK's largest public funded prison project', Pick Everard website. Online. Available HTTP:

http://www.pickeverard.co.uk/news/2012/Pick-Everard-completes-UKs-largestpublic-funded-prison-project.html (accessed 4 February 2014).

_- (no date) 'Custodial and Emergency Services', Pick Everard website. Online. Available HTTP:

http://www.pickeverard.co.uk/custodial-emergency-services/index.html (accessed 3 February 2014).

Pratt, J. and Eriksson, A. (2012) Contrasts in Punishment: An Explanation of Anglophone Excess and Nordic Exceptionalism, London: Routledge.

Pratt, J., Brown, D., Brown, M., Hallsworth, S. and Morrison, W. (eds) (2011) The New Punitiveness: Trends, Theories, Perspectives, Oxford: Routledge.

Premier Construction (2014) 'Unveiling HMP and YOI Grampian', Premier Construction website. Online. Available HTTP:

http://premierconstructionnews.com/2014/02/25/unveiling-hmp-and-yoi-grampian/ (accessed 19 June 2014).

Rose, G., Degen, M. and Basdas, B. (2010) 'More on 'big things': building events and feelings', Transactions of the Institute of British Geographers, 35: 334-49.

Royal Institute of Chartered Surveyors [RICS] (2012) Modus: The Security Issue, 22 $11 / 2012$. 
Schaeffer, M.A., Baum, A., Paulus, P.B. and Gaes, G.G. (1988) 'Architecturally mediated effects of social density in prison', Environment and Behavior, 20(1): 3-20.

Shammas, V.L. (2014) 'The pains of freedom: assessing the ambiguity of Scandinavian penal exceptionalism on Norway's Prison Island', Punishment \& Society, 16(1): 104-23.

Siserman, C. (2012) Reconsidering the Environmental Space of Prisons: A Step Further towards Criminal Reform, Santa Cruz, CA: GRIN Verlag.

Skanska (2012) 'Case Study 98 HMP Thameside', Skanska website. Online. Available HTTP: http://skanska-sustainability-case-studies.com/HMP-Thameside-UK (accessed 16 June 2014).

Snacken, S. (2010) 'Resisting punitiveness in Europe?', Theoretical Criminology, 14(3): 273-92.

Sparks, R., Bottoms, A. and Hay, W. (1996) Prisons and the Problem of Order, Oxford: Clarendon Press.

Spens, I. (ed.) (1994) Architecture of Incarceration, London: Academy Editions.

Stevens, A. (2012) Offender Rehabilitation and Therapeutic Communities: Enabling Change the TC Way, London: Routledge.

Sykes, G.M. (1958) The Society of Captives: A Study of a Maximum Security Prison, Princeton, NJ: Princeton University Press.

Tartaro, C. (2003) 'Suicide and the jail environment: an evaluation of three types of institutions', Environment and Behavior, 35(5): 605-20.

Tonry, M. (2004) Thinking About Crime: Sense and Sensibility in American Penal Culture, Oxford: Oxford University Press.

Townsend, A.M. and Bennett, J.T. (2003) 'Privacy, technology and conflict: emerging issues and action in workplace privacy', Journal of Labor Research, 24(2): 195-205. 
Travis, A. (2010) 'Prison works, says Theresa May', The Guardian. Online. Available HTTP:

http://www.theguardian.com/politics/2010/dec/14/prison-works-says-theresa-may (accessed 3 July 2014).

Ugelvik, T. and Dullum, J. (eds) (2012) Penal Exceptionalism? Nordic Prison Policy and Practice, London: Routledge.

Von Hofer, H. (2003) 'Prison populations as political constructs: the case of Finland, Holland and Sweden', Journal of Scandinavian Studies in Criminology and Crime Prevention, 4(1): 21-38.

Wacquant, L. (2002) 'The Curious Eclipse of Prison Ethnography in the Age of Mass Incarceration', Ethnography 3(4): 371-97.

Wener, R.E. (2012) The Environmental Psychology of Prisons and Jails: Creating Humane Spaces in Secure Settings, Cambridge: Cambridge University Press.

White, A.A. (2008) 'Concept of less eligibility and the social function of prison violence in class societies', The Buffalo Law Review, 56: 737.

Wortley, R. (2002) Situational Prison Control: Crime Prevention in Correctional Institutions, Cambridge: Cambridge University Press.

Young, J. (2003) 'Searching for a new criminology of everyday life: a review of the 'culture of control', British Journal of Criminology, 43(1): 228-43.

Zhang, Z., Spicer, A., and Hancock, P. (2008) 'Hyper-organizational space in the work of JG Ballard', Organization, 15 (6): 889-910. 
${ }^{\mathrm{i}}$ In the UK, a former Home Secretary recalled that he was never asked to adjudicate on matters of prison design, rating 'the prison designs of much of the post-war period' as 'shoddy, expensive and just a little inhuman' (Hurd 2000: xiii-xiv).

ii 1990s security breaches included prisoner rooftop protests at Strangeways in 1990 and escapes from Whitemoor and Parkhurst prisons in 1994.

iii David Nisbet, Partner at Pick Everard (see Pick Everard 2012: no page)

iv To these ends, the authors are currently conducting a three-year research study. Taking a lead from Victor Hassine's biographical writings on his experience as a prisoner in the US system, the project is titled "Fear-suffused environments" or potential to rehabilitate? Prison architecture, design and technology and the lived experience of carceral spaces' [ESRC Standard Grant ES/K011081/1]. 